\title{
Children Coping with Stress During Lockdown
}

\section{Vijay Kumar' ${ }^{1}$, Nishu Chawla ${ }^{2}$, Shipra Gupta ${ }^{3}$, Jigisha Aanad ${ }^{4}$}

\section{IJCRR}

Section: Healthcare

Sci. Journal Impact

Factor: 6.1 (2018)

ICV: 90.90 (2018)

(c) (7) (3)

Copyright@IJCRR
'Professor, Department of Physics, Graphic Era Hill University, Dehardun, Uttrakhand, India; ${ }^{2}$ A. P., Department of Professional Communication, Graphic Era Hill University, Dehardun, Uttrakhand, India; ${ }^{3}$ Associate Professor, Department of Commerce, Graphic Era Hill

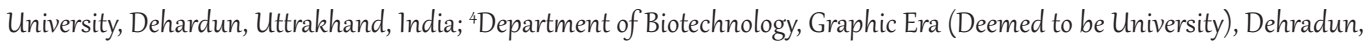
Uttarakhand, India.

\section{ABSTRACT}

Background: The coronavirus disease 2019 (COVID-19) pandemic is having an intense effect on all aspects of society, including mental health and physical health. A major adverse consequence of the COVID-19 pandemic is likely to be increased social isolation and loneliness which are strongly associated with anxiety and depression. Tracking loneliness and intervening early are important priorities. Crucially, reducing sustained feelings of loneliness, and promoting belongingness are candidate mechanisms to protect against self-harm and emotional problems. Social and physical distancing has abruptly interrupted many social opportunities important to physical and psychological health.

Method: In this study, 2140 children of different categories (gender, age, education, region, and location) have participated. The questionnaires depend upon the argument tendency, depressive order, adverse mental problem symptoms, behavioural health symptoms, and anxiety disorder.

Results: It is observed that children face anxiety, depressive disorder, argument tendency and show adverse mental problem symptoms, behavioural health symptoms, and COVID-19 related trauma and stressor-related disorder.

Conclusion: The present paper also deals with how the parents can help the children coping with stress during this COVID-19. Key Words: Coronavirus COVID-19, Children Coping, Depressive disorder, Anxiety disorder, Argument tendency

\section{INTRODUCTION}

Stress is a natural emotion or a feeling of not being able to cope with demands and circumstances. It is a destructive and weakening force. It is very important to manage stress or else it can be fatal. In an inadequate and inconstant world, such as ours, it is impossible to avoid stress. However, being vigilant to the effects of stress may help the children manage more effectively. Elements in our life that cause stress are known as 'stressors'. Stress influences one's mental well being. Mentally healthy children are better able to meet life's challenges. They are also better learners and have stronger relationships ${ }^{1,2}$. Some stress can even lead to serious consequences, because of long-running trouble. One should indeed learn how to deal with the difficult times and progress, as adversities and sufferings are a part of life. Nevertheless, while that process of acquiring knowledge through our thoughts, experiences, and senses is in progress, children depend on sympathetic and empathetic relationships from adults throughout. Therefore notable and trusted adults, parents, close relatives, teachers play a vital role in helping the children out in understanding their needs, desires and minimizing their anxiety and fear ${ }^{3,4}$.

\section{Literature Review}

Children are more likely to be experiencing the same symptoms of fright, worry, impatience as experienced by adults during this pandemic time of COVID 19. Even the researchers agree that sticking to a regular schedule is key, even when you are at home all day. Parents need to tell their children what importance of keeping some structure holds. For example, getting up, good nutrition, proper rest, going to bed around the same time every day is very important. These things can help children to cope with stress. Spending quality time with children is equally essential and will serve the purpose of understanding the children and building good and harmonious relations with them, especially if they have had

\section{Corresponding Author:}

Dr. Shipra Gupta, Associate Professor, Department of Commerce, Graphic Era Hill University, Dehardun, Uttrakhand, India. Email: drshipragupta16@gmail.com

ISSN: 2231-2196 (Print)

Received: 24.07 .2020
ISSN: 0975-5241 (Online)

Revised: 22.08 .2020
Accepted: 3.09 .2020
Published: 22.09 .2020 
a stressful day. Talking with their children, knowing their issues and requirements will let their children come closer to them. The coronavirus disease has deeply affected life around the globe. Solitary confinement, contact restrictions, and economic shutdown impose a complete change to the psychosocial environment in affected countries ${ }^{5,6}$. These steps have the possibilities to intimidate the emotional instability of kids and youngsters notability. Nonetheless, the health crisis can lead to good time or chances for self-development and emotional bonding that family members have towards one another, drawbacks may outrank these advantages. Apprehension, absence of social interaction and minimize options for stress regulation are the main concerns. "Spare time activities have been restricted. In most countries, children have not been permitted to use regular playgrounds". Collective activities are restricted and sports clubs are closed.

Children at this time need extra love and affection ${ }^{7,8}$. So the responsibility of parents has become more and they need to respond to their child's reactions in a supportive way, listening to their concerns and trying and keeping children close to them and Family and avoid departing children and their caretakers to the extent possible. If disconnection takes place (e.g. medication) make sure regular contact (through phone). Provide information about what has happened, disclose what is going on, and give a clear picture to them as to what has happened, and how to reduce the extent of being infected by the disease. Children are given extra care and attention during the challenging periods.

Children are spending their maximum time of theirs online. School, assignments, chats and many more- even music lessons, and other extracurricular activities are being conducted online- everything has shifted online. "Staying connected with children helps them to lessen the impact of this COVID-19 which is spread worldwide and encourage them to keep going in their lives. At the same time, it is a big challenge for parents. How can you have the best that the entire internet has to offer while minimizing harm? It is not easy to have an equilibrium when undergoing a health emergency like COVID-199,10.

There are various ways parents can help to keep their children safe online.

Children hope to enter into an honest dialogue that looks at the problems. It is the moral duty of parents to be supportive and kind in knowing their children's problems and to try to solve them by interacting with them. Parents always need to be very cautious if their child seems to be distressed and reticent with electronic activities or if they are undergoing any kind of harassment by sending or posting mean messages, usually anonymously ${ }^{11}$.

Parents should make use of the latest multimedia to safeguard them. Make it sure that your youngster is using the updated application and the privacy settings are on. For little children, appliances likewise content filter, as well as secure search, can assist digital experience constructive ${ }^{12}$.

Generate chances for your youth to possess a positive and safe digital association.

Helping kids deal with stress during lockdown is very important. However isolation, physical, and social distancing are the new normal, it has led to enormous physical and psychological pressure on the kids. Closures of schools have restricted the movement of children and they are enforced to stay at home with their adults and caretakers who are already exhausted and fatigued. Children who are in confinement or segregated or maybe away from adult administration may also intensify protection risks. "Children with disorders may suffer from stronger consequences of the in-progress widespread disease. They might have severe discomfort, anguish, or worry as they have less control over themselves than other people. The same case is with children with physical, psychological, or mental limitations. They may need extra attention, more clarifications about the prevailing circumstances, and more sympathy and other productive reinforcement of messages. Devote time with them, care about their needs. So that they show their active participation in all activities ${ }^{13,14}$. Youth bearing anxiety and pain is quite natural during in progress pandemic like COVID-19. Being frightened about their health and the health and the health of their dearest ones can be massive and cause strong emotions. In today's era of the information age, children also acquire different kind of information and news from various online platforms and digital media, of which some may be genuine and some may be unreal as well as causing stress and fright and this may increase when they are not able to go out and spend their leisure time with friends or attend the school where they can interact freely. Parents and caretakers should act sensibly when it comes to rumours and unreliable information. Parents should be extra attentive in dealing with such things so that their children do not face the consequences of $\mathrm{it}^{15,16}$.

It is very important for parents to be happy for only happy parents can create a happy generation. Parents who remain stress-free can teach their children to lead a stress-free life. Children don't like talking to parents who are always under stress. Some the reasons for parents being stressed out are that some parents always carry the burden of their past incidents and make their present suffer because of which the children are not able to communicate freely with their parents as they (parents) devote much of their time recalling their past and not able to communicate well with their children and the result is seen in the formed gap between them, speaking authoritatively with their children and not understanding their point, constantly finding mistakes in their children and shouting and demeaning them and not accepting their mistakes in front of the children, having high expectations from 
their children without realizing that their children to have some expectations. So parents need to introspect themselves and know where they are lacking and what can be done for self-improvement for building a better relationship with their children $^{17,18,19}$.

\section{Methods}

COVID-19, coronavirus pandemic has been associated with the mental health of the children. Due to the pandemic, the children were at home. They could not go out for sports, for attending coaching classes, for attending classes in school. It becomes a reason for adverse mental or behavioural health conditions, anxiety disorder, and trauma-related disorder. In this manuscript, 2140 children are selected for this study.
The selection has been done in such a way that the students of all categories are included in this study. In this study, students of various age groups, different schools, various classes, and children from hostels are selected. The children are also selected which belong to a poor family and rich family. This study has been done for the lockdown period i.e., from 1 to 30 April 2020. The children are also taken from different states of India for this study. The argument tendency, depressive disorder, COVID-19-related Trauma, and Stressor-related disorder, adverse mental problem symptoms, behavioural health symptoms, anxiety disorder have been discussed with the children. The classification of children is done concerning gender, age groups, school boards, education, region (state or national), rural and urban.

\section{Statistical Analysis}

\section{OBSERVATIONS}

Table 1: Respondent characteristics of outcomes of mental health, increased substance use to cope stress of children related to COVID-19 pandemic-India, 1 to 30 April 2020

\begin{tabular}{|c|c|c|c|c|c|c|c|}
\hline Characteristics & $\begin{array}{c}\text { Respondents } \\
\text { who completed } \\
\text { surveys from } 1 \\
\text { to } 30 \text { April } 2020 \\
(\%)\end{array}$ & $\begin{array}{l}\text { Argument } \\
\text { tendency }\end{array}$ & $\begin{array}{l}\text { Depressive } \\
\text { disorder }\end{array}$ & $\begin{array}{l}\text { COVID-19 } \\
\text { related } \\
\text { TSRD\# }\end{array}$ & $\begin{array}{l}\text { Adverse } \\
\text { mental } \\
\text { problem } \\
\text { symptoms }\end{array}$ & $\begin{array}{l}\text { Behavioural } \\
\text { health symp- } \\
\text { toms }\end{array}$ & $\begin{array}{l}\text { Anxiety } \\
\text { disorder }\end{array}$ \\
\hline All respondents & $2140(100)$ & $870(41.58)$ & $795.5(37.17)$ & $657(30.70)$ & $540.5(25.25)$ & $648.5(30.30)$ & $538.5(25.16)$ \\
\hline \multicolumn{8}{|l|}{ Gender } \\
\hline Male & $1013(47 \cdot 3)$ & $910(42.5)$ & $978(45 \cdot 7)$ & $729(34.06)$ & $591(27.61)$ & $832(38.8)$ & $690(32.2)$ \\
\hline Female & $727(33.9)$ & $706(33)$ & $613(28.6)$ & $585(27 \cdot 3)$ & $490(22.89)$ & $465(21.72)$ & $387(18.08)$ \\
\hline Not respondents & $400(18.6)$ & $524(24 \cdot 48)$ & $549(25.65)$ & $826(38.59)$ & $1059(49.48)$ & $843(39.39)$ & $1063(49.67)$ \\
\hline \multicolumn{8}{|l|}{ Age groups } \\
\hline 6 to 10 years & $373(17 \cdot 4)$ & $178(8.31)$ & $78(3.64)$ & $59(2.75)$ & $93(4 \cdot 34)$ & $376(17 \cdot 57)$ & $240(11.21)$ \\
\hline 10 to 15 years & $487(22.75)$ & $374(17.47)$ & $197(9.20)$ & $290(13.55)$ & $194(9.06)$ & $267(12.47)$ & $170(7.94)$ \\
\hline 15 to 20 years & $603(28.17)$ & $477(22.28)$ & $386(18.03)$ & $376(17.57)$ & $248(11.58)$ & $476(22.24)$ & $492(22.99)$ \\
\hline 20 to 25 years & $525(24 \cdot 5)$ & $592(27.66)$ & $467(21.82)$ & $456(21.3)$ & $413(19.29)$ & $530(24 \cdot 76)$ & $480(22.42)$ \\
\hline Not respondents & $152(7.10)$ & $519(24.25)$ & $1012(47.28)$ & $959(44.81)$ & $774(36.16)$ & $491(22.94)$ & $758(35.42)$ \\
\hline \multicolumn{8}{|c|}{ Students from different schools } \\
\hline $\begin{array}{l}\text { State level schools } \\
\text { students }\end{array}$ & $758(3.4)$ & $832(38.8)$ & $378(17 \cdot 6)$ & $458(21.4)$ & $419(19 \cdot 5)$ & $497(23.2)$ & $482(22.5)$ \\
\hline $\begin{array}{l}\text { Central level } \\
\text { schools students }\end{array}$ & $996(46.54)$ & $967(45.1)$ & $795(37.1)$ & $676(31.58)$ & $528(24.6)$ & $518(24.2)$ & $587(27 \cdot 4)$ \\
\hline Not respondents & $386(18)$ & $341(15 \cdot 9)$ & $967(45.18)$ & $1006(47)$ & $1193(55 \cdot 74)$ & $1125(52.57$ & $1071(50)$ \\
\hline \multicolumn{8}{|l|}{ Education } \\
\hline $\begin{array}{l}1^{\text {st }} \text { to } 5^{\text {th }} \text { class stu- } \\
\text { dents }\end{array}$ & $167(7.8)$ & $132(6.16)$ & $56(2.61)$ & $89(4.15)$ & $67(3.13)$ & $290(13.55)$ & $294(13.73)$ \\
\hline $\begin{array}{l}6^{\text {th }} \text { to } 8^{\text {th }} \text { class } \\
\text { students }\end{array}$ & $579(27)$ & $403(18.83)$ & $189(8.83)$ & $190(8.87)$ & $274(12.8)$ & $195(9.11)$ & $380(17.75)$ \\
\hline $\begin{array}{l}9^{\text {th }} \text { to } 10^{\text {th }} \text { class } \\
\text { students }\end{array}$ & $613(28.6)$ & $367(17.14)$ & $276(12.89)$ & $297(13.87)$ & $392(18.31)$ & 299 (13.97) & $472(22.05)$ \\
\hline
\end{tabular}


Table 1: (Continued)

\begin{tabular}{|c|c|c|c|c|c|c|c|}
\hline Characteristics & $\begin{array}{c}\text { Respondents } \\
\text { who completed } \\
\text { surveys from } 1 \\
\text { to } 30 \text { April } 2020 \\
(\%)\end{array}$ & $\begin{array}{l}\text { Argument } \\
\text { tendency }\end{array}$ & $\begin{array}{l}\text { Depressive } \\
\text { disorder }\end{array}$ & $\begin{array}{l}\text { COVID-19 } \\
\text { related } \\
\text { TSRD\# }\end{array}$ & $\begin{array}{l}\text { Adverse } \\
\text { mental } \\
\text { problem } \\
\text { symptoms }\end{array}$ & $\begin{array}{l}\text { Behavioural } \\
\text { health symp- } \\
\text { toms }\end{array}$ & $\begin{array}{l}\text { Anxiety } \\
\text { disorder }\end{array}$ \\
\hline $\begin{array}{l}11^{\text {th }} \text { and } 12^{\text {th }} \text { class } \\
\text { students }\end{array}$ & $525(24 \cdot 5)$ & $617(28.8)$ & 689 (32.19) & $739(34 \cdot 53)$ & $598(27.94)$ & $378(17.66)$ & 368 (17.19) \\
\hline Not respondents & $256(11.9)$ & $519(24.25)$ & $930(43.45)$ & $825(38.55)$ & $809(37.8)$ & $978(45 \cdot 7)$ & $626(29.25)$ \\
\hline \multicolumn{8}{|l|}{ Region } \\
\hline Northeast & $494(23)$ & $547(25 \cdot 56)$ & $478(22.33)$ & $389(18.17)$ & $294(13.73)$ & $376(17.5)$ & $384(17.94)$ \\
\hline Mideast & $345(16.12)$ & $309(14.43)$ & $397(18.55)$ & $473(22.10)$ & $378(17.66)$ & $270(12.6)$ & $284(13.27)$ \\
\hline South & $507(23.69)$ & $207(9.67)$ & $490(22.89)$ & $391(18.27)$ & $485(22.66)$ & $482(22.5)$ & $502(23.45)$ \\
\hline West & $654(30.14)$ & $738(34.48)$ & $673(31.44)$ & $693(32.38)$ & $190(8.87)$ & $520(24.29)$ & $481(22.47)$ \\
\hline Not respondents & $140(6.5)$ & $339(15.84)$ & $102(4 \cdot 76)$ & $194(9.06)$ & $793(37.05)$ & $492(22.99)$ & $489(22.85)$ \\
\hline \multicolumn{8}{|c|}{ Rural-Urban classification } \\
\hline Rural & $833(38.9)$ & $913(42.6)$ & $837(39.1)$ & $290(13.55)$ & $389(18.1)$ & $490(22.89)$ & $395(18.45)$ \\
\hline Urban & $965(45)$ & $1045(48.8)$ & $943(44)$ & $792(37)$ & $278(12.99)$ & $582(27.19)$ & $581(27.14)$ \\
\hline Not respondents & $342(15 \cdot 98)$ & $182(8.5)$ & $360(16.82)$ & $1058(49.43)$ & $1473(68.8)$ & $1068(49 \cdot 9)$ & $1164(54 \cdot 39)$ \\
\hline
\end{tabular}

\section{DISCUSSION}

Out of 2140 children, $47.3 \%$ boys, $33.9 \%$ of girls have given responses. In this lockdown period, people and children are not able to move out of the house. Due to this, the behaviour of children was changed. The behaviour and health were observed during this lockdown period. Table 1 represents that $42.5 \%$ and $33 \%$ argument tendency have been increased in boys and girls while no effect was observed in $24.48 \%$ children in this period. The depressive disorder has been shown by $45.7 \%$ in boys, $28.6 \%$ in girls while $25.65 \%$ shown no such type of effect. $34.06 \%$ boys, $27.3 \%$ of girls were observed COVID-19 related trauma and stressor-related disorder and no effect was observed in $38.59 \%$ children. During the lockdown, children were facing a mental pressure of this pandemic. Adverse mental problem was shown by $27.17 \%$ boys, $22.89 \%$ girls, and no effect was shown by $49.48 \%$ of children. Behavioural health symptoms were found in $38.8 \%$ boys, $21.72 \%$ girls and no symptoms were found in $39.39 \%$ children. $32.2 \%$ boys and $18.08 \%$ of girls were observed by an anxiety disorder and $49.67 \%$ were observed no effect.

Different types of symptoms are observed during this period. Behavioural health symptoms were shown by $17.57 \%$ children and COVID-19 related TSRD shown by only $2.75 \%$ children (6 to 10 years). When a survey was done on students aged between 10 to 15 years, it was found that $7.94 \%$ children were suffering a problem of anxiety disorder and $17.47 \%$ of children were increased the tendency of argument. In 15 to 20 years children, adverse mental problem symptoms were found in $11.58 \%$ and anxiety disorder was found in $22.99 \%$ of children. $19.29 \%$ and $24.76 \%$ of chil- dren (20 to 25 years age group) were suffering the problem of adverse mental symptoms and behavioural health problems, respectively. Children were also divided into another category i.e., education system. In this system, one category was taken in which students were selected from the State (Uttarakhand, Uttar Pradesh, M. P., Punjab, Haryana) Board, etc. and the second category was selected from the national board (CBSE, ISC, etc.). It was observed that in state-level students, $17.6 \%$ were facing and $23.2 \%$ were facing Behavioral health symptoms. In National board students, $24.2 \%$ were facing Behavioral health symptoms and $37.1 \%$ were facing the problem of depressive disorder. As per the analysis done on the students of various classes, the students from $1^{\text {st }}$ to $10^{\text {th }}$ class standard were suffering the same problem. The anxiety disorder problem was suffered by the maximum students and the dispersive disorder problem was faced by some percentage of students.

The children from the north-east, mid-east, south, and west were also selected for this study. The children of all sides were also facing the above-mentioned problem. It was observed that $13.73 \%$ of children were found adverse mental health symptoms and $25.56 \%$ of children were facing the problem of argument tendency from the north-east side. $12.6 \%$ and $22.1 \%$ of children of the mid-east side were facing Behavioral health symptoms and COVID-19 related TSRD problems, respectively. In the south side, $9.67 \%$ of children have started argument tendency and in $23.45 \%$ of children were found anxiety disorder. In $8.87 \%$ of children were found suffering from adverse mental problem symptoms and in $34.48 \%$ of children, the argument tendencies were increased in the south side. Table 2 shows that $(17.9 \%$ - 
25.6\%) children accepted that they knew COVID-19 was responsible to increase argument tendency, depressive disorder, TSRD, adverse mental problem symptoms, behavioural health symptoms, and anxiety disorder. (19.9\%-27.3\%) children did not accept that COVID-19 was responsible for the above-given problems. (26.3\%-31.1\%) children knew that prehistory heart patients may become severe during this pandemic. (19.5\%-33.2\%) children were not aware of that. The pandemic may create trouble for prehistory lung patients. (29.3\%-37.2\%) children were accepted for that and (28.9\%-38.4\%) were not known about this. (32.5\%-41.2\%) children agreed that coronavirus may become harmful for diabetic patients and (37.4\%-48.31\%) children did not agree with this assumption. (16.3\%-42.3\%) children accepted that the pandemic period may be harmful to high blood pressure patient while (29.5\%-38.2\%) children did not agree for that. (20.7\%-29.4\%) children have given their consent that kidney patients may be in danger while (14.4\%-38.5\%) did not agree with this assumption. The people who were affected by the diseases of the abdomen may be in trouble in the pandemic. (14.1\%-31.8\%) children were accepted for that while $(25.2 \%-49.3 \%)$ were not agreed on that. $(15.2 \%-29.4 \%)$ children were assumed that pandemic will produce mental pressure to the people while $(26.3 \%-38.5 \%)$ were not satisfied with this assumption.

Table 2: Respondent characteristics of outcomes of mental health, increased substance use to cope stress of children related to COVID-19 pandemic-India, 1 to 30 April 2020

\begin{tabular}{|c|c|c|c|c|c|c|c|}
\hline Characteristics & $\begin{array}{c}\text { Respondents who } \\
\text { completed surveys } \\
\text { from } 1 \text { to } 30 \text { April } 2020 \\
(\%)\end{array}$ & $\begin{array}{l}\text { Argument } \\
\text { tendency }\end{array}$ & $\begin{array}{c}\text { Depressive } \\
\text { disorder }\end{array}$ & TSRD & $\begin{array}{l}\text { Adverse } \\
\text { mental } \\
\text { problem } \\
\text { symptoms }\end{array}$ & $\begin{array}{l}\text { Behavioural } \\
\text { health symp- } \\
\text { toms }\end{array}$ & $\begin{array}{l}\text { Anxiety } \\
\text { disorder }\end{array}$ \\
\hline
\end{tabular}

Someone who knew about the symptoms of COVID-19

\begin{tabular}{|c|c|c|c|c|c|c|}
\hline Yes & $486(22.7)$ & $548(25.6)$ & $466(21.8)$ & $383(17.9)$ & $437(20.4)$ & $419(19.6)$ \\
\hline No & $1654(77 \cdot 3)$ & $462(21.6)$ & $584(27 \cdot 3)$ & $554(25.9)$ & $426(19.9)$ & $477(22.3)$ \\
\hline
\end{tabular}

Undertreatment for previously diagnosed problems (Heart)

\begin{tabular}{|c|c|c|c|c|c|c|}
\hline Yes & $644(30.1)$ & $631(29.5)$ & $614(28.7)$ & 666 (31.1) & $584(27 \cdot 3)$ & $563(26.3)$ \\
\hline No & $584(27 \cdot 3)$ & $417(19.5)$ & $484(22.6)$ & $627(29 \cdot 3)$ & $710(33.2)$ & $687(32.1)$ \\
\hline
\end{tabular}

Undertreatment for previously diagnosed problems (Lungs)

\begin{tabular}{|c|c|c|c|c|c|c|}
\hline Yes & 747 (34.9) & $670(31.3)$ & $740(34.6)$ & $627(29.3)$ & $755(35 \cdot 3)$ & $785(36.7)$ \\
\hline No & $426(19.9)$ & $708(33.1)$ & $822(38.4)$ & $805(37.6)$ & $725(33.9)$ & $668(31.2)$ \\
\hline
\end{tabular}

Undertreatment for previously diagnosed problems (Sugar)

$\begin{array}{llllllll}\text { Yes } & 839(39.2) & 826(38.6) & 882(41.2) & 798(37.3) & 777(36.3) & 858(40.1) & 695(32.5) \\ \text { No } & 758(35.4) & 415(19.4) & 1012(47.3) & 969(45.3) & 948(44.3) & 801(37.4) & 1034(48.31)\end{array}$

Undertreatment for previously diagnosed problems (High Blood Pressure)

\begin{tabular}{|c|c|c|c|c|c|c|c|}
\hline Yes & $884(41 \cdot 3)$ & $905(42.3)$ & $865(40.4)$ & $805(37.6)$ & $629(29.4)$ & $349(16.3)$ & $826(38.6)$ \\
\hline No & $537(25.1)$ & $629(29.4)$ & $674(31.5)$ & $732(34.2)$ & $817(38.2)$ & $758(35.4)$ & $631(29.5)$ \\
\hline \multicolumn{8}{|c|}{ Undertreatment for previously diagnosed problems (kidney) } \\
\hline Yes & $862(40.3)$ & $989(46.2)$ & $629(29 \cdot 4)$ & $586(27.4)$ & $608(28.4)$ & $554(25 \cdot 9)$ & $443(20.7)$ \\
\hline No & $672(31.4)$ & $1226(57 \cdot 3)$ & $653(30.5)$ & $824(38.5)$ & $370(17 \cdot 3)$ & $308(14 \cdot 4)$ & $681(31.8)$ \\
\hline \multicolumn{8}{|c|}{ Undertreatment for previously diagnosed problems (abdomen) } \\
\hline Yes & $839(39.2)$ & $1226(57 \cdot 3)$ & $653(30.5)$ & $349(16.3)$ & $845(39.5)$ & $302(14.1)$ & $681(31.8)$ \\
\hline No & $434(20.3)$ & $1464(68.4)$ & $1055(49 \cdot 3)$ & $586(27 \cdot 4)$ & $862(40.3)$ & $539(25.2)$ & $918(42.9)$ \\
\hline \multicolumn{8}{|c|}{ Undertreatment for previously diagnosed problems (Mental Stress) } \\
\hline Yes & $601(28.1)$ & $989(46.2)$ & $629(29.4)$ & $582(27.2)$ & $437(20.4)$ & $325(15.2)$ & $490(22.9)$ \\
\hline No & $839(39.2)$ & $798(37.3)$ & $824(38.5)$ & $820(38.3)$ & $674(31.5)$ & $563(26.3)$ & $708(33.1)$ \\
\hline
\end{tabular}




\section{CONCLUSION}

In this study of 2140 children, we found that pandemic had produced many severe problems in the whole world. The lockdown period due to the pandemic produced many types of different problems. The children, who moved here and there, have become prisoners in their homes. It produced many types of biological and mental problems in children. In this manuscript, it is observed that in children's argument tendency was increased. The other problems which the parents were feeling are anxiety disorder, depressive disorder, adverse mental problem symptoms, behavioural health symptoms, and COVID-19 related Trauma and Stressor related disorder. The COVID-19 pandemic is potentially catastrophic for many children around the world. Its impact risks unravelling global progress across several of the Sustainable Development Goals for children, putting already ambitious targets out of sight. Put simply, we cannot afford to let this happen. It is suggested to the people that in this type of scenario, the children feel mental pressure so the parents should be interactive with their kids.

Acknowledgement: Authors of this manuscript are grateful to the management of Graphic Era Hill University Dehradun who provides us with all necessary facility for this study and also grateful to all the children and their parents who are seriously involved in this study. Authors are grateful to the researchers whose article are cited and references in this manuscript. The authors are also grateful to the editors of this journal for providing necessary guidelines for publication of this study.

\section{Conflict of interest: None}

Financial support: None

\section{REFERENCES}

1. Effects of stress on children (Kids Matters Webinar, 6 April 2016), https://www.cdchk.org/parent-tips/effects-of-stress-onchildren.

2. Oboho, I.K.; Tomczyk, S.M.; Al-Asmari, A.M.; Banjar, A.A.; Al-Mugti, H.; Aloraini, M.S.; Alkhaldi, K.Z.; Almohammadi, E.L.; Alraddadi, B.M.; Gerber, S.I.; et al. 2014 MERS-CoV Outbreak in Jeddah-A Link to Health Care Facilities. N. Engl. J. Med. 2015, 372, 846-854.

3. Kampf G; Todt D, Pfaender S, Steinmann E. Persistence of coronaviruses on inanimate surfaces and they are inactivation with biocidal agents, J of Hospital Infection, 2020; 104: 246-251.

4. Challenges and burden of the Coronavirus 2019 (COVID-19) pandemic for child and adolescent mental health: a narrative review to highlight clinical and research needs in the acute phase and the long return to normality https://www.ncbi.nlm.nih.gov/ pmc/articles/PMC7216870/April 2020
5. The Korean Society of Infectious Diseases; Korean Society for Healthcare-associated Infection Control and Prevention. An Unexpected Outbreak of Middle East Respiratory Syndrome Coronavirus Infection in the Republic of Korea, 2015. Infect. Chemother. 2015, 47, 120-122.

6. Yen MY, Lu Y C, Huang PH, Chen CM, Chen Y C, Lin Y E, Quantitative evaluation of infection control models in the prevention of nosocomial transmission of SARS virus to health care workers: implications to nosoconia viral infection control for health care workers, Scand J Infect Dis, 2010; 42: 510-5.

7. Alshammari M, Reynold K A, Verhougstraete M, O'Rourke M $\mathrm{K}$. Comparison of persisved and observed and higene compliance in health care workers in MERS- CoV endemic reasons. Health care (Basel, Switzerland) 2018; 6: 122.

8. Nine Ways To Help Your Kids Manage Stress During the Lockdown https://www.healthifyme.com/blog/9-ways-to-help-yourkids-manage-stress-during-the-lockdown/April 2020

9. Huang et al, The Lancet, January 24, 2020, Clinical features of patients infected with 2019 novel coronavirus in Wuhan, China.

10. Wang et al Clinical characteristics of 138 hospitalized patients with 2019 novel coronavirus-infected Pneumonia in Wuhan China-JAMA, , February 72020.

11. WHO, Coronavirus Disease 2019 (COVID-19). WHO; 2020. Situation Report 23, April 2020.

12. Psychosocial Support for Children during COVID-19 A Manual for Parents and Caregivers https://www.unicef.org/india/ media/3401/file/PSS-COVID19-Manual-ChildLine.pdf, April 2020 .

13. Jin YH, Cai L, Cheng ZS, Cheng H, Deng T, Fan YP, et al. A rapid advice guideline for the diagnosis and treatment of 2019 novel coronavirus (2019-nCoV) infected pneumonia (standard version) . Military Medical Research, 2020; 7 (1): 4.

14. Mahtani S, Berger M, O'Grady S, Iati M. Hundreds of evacuees to be held on bases in California; Hong Kong and Taiwan restrict travel from mainland China. The Washington Post. Archived from the original on 7 February 2020. Retrieved 11 February 2020.

15. Chen N, Zhou M, Dong X, Qu J, Gong F, Han Y, et al. Epidemiological and clinical characteristics of 99 cases of 2019 novel coronavirus pneumonia in Wuhan, China: a descriptive study. Lancet. 2020;395: 507-513.

16. World Health Organization. Coronavirus disease 2019 (COVID-19): situation report, 47”.WHO,March 2020. hdl:10665/331444.

17. Stress Free Parenting in 21st Century, https://gurukul.org/ blog/21st-century-parenting/stress-free-parenting-in- $21^{\text {st }}$ century/?gclid=Cj0KCQjw7Nj5BRCZARIsABwxDKKKv16rv7p9IF Hp29Iej3oYFhg1Z7SqH19CdvNL0qT3OXFlo-H9JNYaAsD3E ALw_wcB April 2020.

18. Sanjay M, Md. Irfan A, Bhoomika A, Ashish G. Use of Newer Protective and Disinfection Strategies: A Simple Tool Guide for the Dentists During the COVID-19 Pandemic International Journal of Current Research and Review. 2020 12;16:151-154.

19. M. E. Czeisler et al. Mental health, substance use, and suicidal ideation during the COVID-19 pandemic-United States, Centers for Disease Control and Prevention, Morbility and Mortality Weekly Report, Vol 69 (32) June 24-30, 2020. 